ppi $201502 Z U 4645$

Esta publicación científica en formato digital es continuidad de la revista impresa ISSN-Versión Impresa 0798-1406 / ISSN-Versión on line 2542-3185Depósito legal pp $197402 Z$ U34

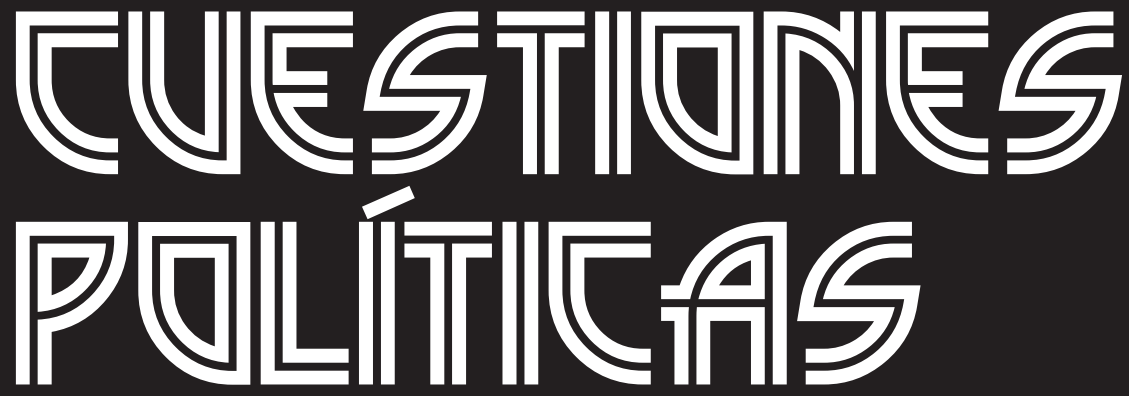

Instituto de Estudios Políticos y Derecho Público "Dr. Humberto J. La Roche" de la Facultad de Ciencias Jurídicas y Políticas de la Universidad del Zulia Maracaibo, Venezuela
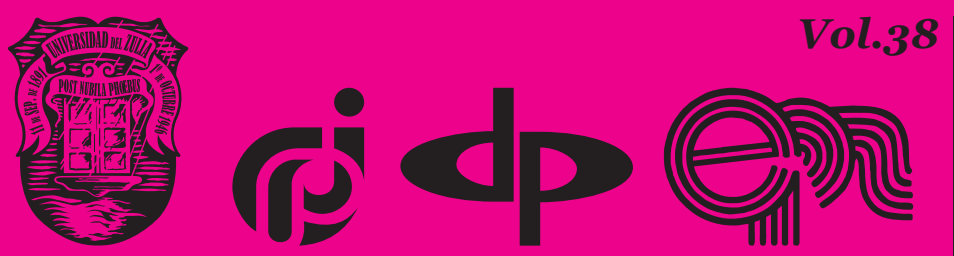

$N^{\circ}$ Especial 1era Parte 2020 


\title{
Assessment of Potential Risks of Regional for Global Financial Security
}

\author{
DOI: https://doi.org/10.46398/cuestpol.38e.10
}

\begin{abstract}
Alexandra Yuryevna Bokovnya *
Zarina Ilduzovna Khisamova **

Vitalii Fedorovich Vasyukov ***

Ildar Rustamovich Begishev ****
\end{abstract}

\begin{abstract}
The objective of the research was to assess the potential risks of stable CBDC digital currencies,alsoknown as coins, for global financial security.. For several years we have seen the phenomenon of «de-dollarization» in the international financial market; this is a gradual transition in abandoning the use of the US dollar in central bank payments and reserves. A key step in the strategy of freeing countries from the US dollar was the creation of national digital currencies, i.e. stable CBDC currencies. To systematize the data obtained, methods of functional and institutional classification, statisticalanalysisand, also, retrospective, currentand future methods of analysis and synthesis of theoretical and practical material were used.. It is concludedthat the rejection of the stable currency Libra was motivated by the possibility of its transformation into a competing system of traditional currencies. The emergence of a private CBDC prompted central banks and regional associations to create their own CBDCs that could compete with the US dollar in international payments. However, the emergence of CBDC is associated with undeniable advantages and objective risks to the existing
\end{abstract} financial system and its security.

Keywords: de-dollarization; legal regulation; digital economy; cryptocurrency; CBDC cryptoactives.

\footnotetext{
* $\quad$ Ph. D. in Law, Faculty of Law, Department of Criminal Law, Kazan Federal University Kazan, Russia (Russian Federation). ORCID ID: https://orcid.org/oooo-0oo2-6395-0893. Email: kafedra.ksu@ yandex.ru

** Ph. D. in Law, Department of Planning and Coordination of Research Activities, Head, Research Department, Krasnodar University of the Ministry of Internal Affairs of the Russian Federation, Krasnodar, Russia (Russian Federation). ORCID ID: https://orcid.org/oooo-00o3-0561-8718. Email: alise89@inbox.ru

*** Doctor of law, Moscow state Institute of international relations (University), Moscow, Russia Orel legal Institute of the Ministry of Internal Affairs of Russia named after V. V. Lukyanov, Orel. ORCID ID: https://orcid.org/oooo-0003-0743-5616. Email: vvfo109@yandex.ru

**** Ph. D. in Law, Senior Researcher, Kazan Innovative University named after V.G. Timiryasov, Kazan, Russia (Russian Federation). ORCID ID: https://orcid.org/oooo-0oo1-5619-4025 e-mail: begishev@ mail.ru
} 


\section{Evaluación de los riesgos potenciales de monedas digitales nacionales estables para la seguridad financiera mundial}

\section{Resumen}

El objetivo de la investigación fue evaluar los riesgos potenciales de monedas digitales estables CBDC, también conocidas como coins, para la seguridad financiera mundial. Desde hace varios años se observa el fenómeno de la "desdolarización" en el mercado financiero internacional; se trata una transición gradual en el abandono del uso del dólar estadounidense en los pagos y reservas mundiales de los bancos centrales. Un paso fundamental en la estrategia de liberar a los países del dólar estadounidense fue la creación de monedas digitales nacionales, es decir, monedas estables CBDC. Para sistematizar los datos obtenidos, se utilizaron métodos de clasificación funcional e institucional, análisis estadístico y, también, métodos de análisis y síntesis retrospectivos, actuales y futuros de material teórico y práctico. Se concluye que el rechazo de la moneda estable Libra estuvo motivado por la posibilidad de su transformación en un sistema competidor de las monedas tradicionales. La aparición de una CBDC privada impulsó a los bancos centrales y las asociaciones regionales a crear sus propias CBDC que podrían competir con el dólar estadounidense en los pagos internacionales. Sin embargo, la aparición de CBDC se asocia con ventajas innegables y riesgos objetivos para el sistema financiero existente y su seguridad.

Palabras clave: desdolarización; regulación legal; economía digital; criptomoneda; criptoactivos CBDC.

\section{Introduction}

The virtually unlimited possibilities in the financial sector opened by digitalization are actively transforming not only financial institutions and instruments but also leading to a qualitative review of existing relationships in the financial sector. The introduction of digital institutions and alternative systems of interstate settlements based on the "blockchain" technology can usher in a new stage in the development of the international financial system (Begishev and Khisamova, 2018; Begishev et al., 2020).

The Western European states have no will to move to a multipolar world where the injustice of the global financial and economic architecture exists; the latter does not take into account the growing influence of emerging market economies. This injustice could be eliminated through the reform of 
Alexandra Yuryevna Bokovnya, Zarina Ilduzovna Khisamova, Vitalii Fedorovich Vasyukov y Ildar Rustamovich Begishev

key institutions of the Bretton Woods system (the International Monetary Fund (IMF) and the World Bank Group). The unwillingness mentioned above has predetermined the need for developed countries in creating alternative financial systems.

This problem became particularly acute in the context of the "tough" sanctions policy of the Western European countries and the United States of America (USA) against Russia and the active trade war between the USA and China, which was named among the key threats to the stability of the global financial system.

Separately, it is worth noting the growing role of transnational corporations and tech giants such as Facebook, which saw in new financial instruments the opportunity to significantly expand their sphere of influence on the financial relationships of users.

The harsh criticism of Facebook from most countries for its trying to create its own digital currency, Libra, was also added with threats of using tough sanctions policy against companies that co-founded Libra, in particular, such payment giants like Visa, MasterCard, Stripe and eBay. This, ultimately, led to their withdrawal from the project in view of the "blurring of the regulation boundaries of the stable coin" (Fusaro and Hougan, 2019).

Central banks have said that Facebook's potentially huge cross-border payment coverage will make it instantly a systemic competitor to traditional currencies. In turn, the European Central Bank (ECB) has banned the circulation of the stable-coin of the Libra type until the creation of an effective regulatory mechanism for their circulation.

The creation of Libra provided a new impetus to the development of the Central Bank Digital Currency (CBDC) concept. Some countries began actively introducing bans on stable-coins, while others, on the contrary, intensified their development in the field of creating state cryptocurrencies (Corbet et al., 2018).

A report by the Financial Stability Board (FSB) for the Group of Seven (G7) notes that global the stable-coin pose a threat to the global financial system and their launch is impossible until legal, regulatory and supervisory risks would be addressed.

Theconceptoffinancialsecurityisthesubjectofinterdisciplinaryresearch. In the legal literature, there are several approaches to understanding this concept, however, in our opinion, the most comprehensive approach to understanding financial security was proposed by Vorobyov and Poritsky (Vorobyov and Poritsky, 2015). As E.V. Kudryashova rightly notes, economic science and management to date have proposed qualitative and quantitative criteria for assessing the level of financial security 
(Kudryashova, 2019). There is a direct correlation between financial and economic security. Financial security should be considered as part of economic security and, ultimately, as a component of national security, and one of its key components, because lowering the level of financial security can lead to loss of financial stability and solvency by the state (Khabrieva, 2016). In this regard, the assessment of potential risks of the impact on the financial security of a new financial instrument, such as the stable-coin, is of particular importance.

In a new report by the Bank for International Settlements (BIS) on digital payments, central banks are encouraged to consider CBDC as "their future." It is noted that the release of CBDC could lead to serious changes in the financial ecosystem.

Within the framework of this paper, the authors attempted to analyse the essence of stablecoins as a new financial instrument and to assess the potential and imaginary risks associated with their spread for global financial security.

\section{Materials and methods}

The study is based on a wide range of international sources, as well as data from international organizations, national legislation and scientific literature. As part of the study, we analysed official documents of Group of Twenty (G20), G7, FSB, at European Union (EU) aimed at assessing the threats posed by stablecoins to the global economy.

During the study, methods of system analysis, dialectic and its derivatives, methods and principles of determinism, induction, deduction and hypothesis were successfully applied. To systematize the obtained data, methods of functional and institutional classification, statistical analysis, and also methods of retrospective, current and future analysis and synthesis of theoretical and practical material were used.

\section{Results}

CBDC represents digital financial assets issued by central banks. Exaggeratedly speaking, the main difference between CBDC and traditional fiat money is that CBDC is a central bank obligation expressed in existing payment units, which can serve as a means of exchange (settlement), storage of value and payment method, that is, to fulfil all fiat money functions, however, operating on the basis of blockchain technology. 
Alexandra Yuryevna Bokovnya, Zarina Ilduzovna Khisamova, Vitalii Fedorovich Vasyukov y Ildar Rustamovich Begishev

CBDCs are a special case of the stable-coins, which are understood as a digital financial asset, the current value of which is provided by one of the traditional and liquid types of assets, i.e. with currency, commodity values, assets accepted in world financial practice, as a reliable and legal means of calculation.

Traditionally, it is customary to distinguish three varieties of stable coins: those secured by a fiat currency or other liquid assets (Tether, TrueUSD, USDC); secured by cryptocurrency, where tokens/coins (MakerDAO) are used as a security deposit instead of the fiat currency, and not secured coins, where the nominal value is ensured thanks to the work of a smart contract (Nabilou, 2019).

In turn, there are four groups of coins in the report of the ECB:

- Tokenized coins (Tether, USD Coin, Paxos, etc.), which are secured by assets held by the issuer in custody;

- Stablecoins with off-chain support (Sweetbridge) by the issuer with assets of other traditional classes;

- Stablecoins provided by on-chain assets (i.e. crypto assets Dai, Aurora);

- Algorithmic stable-coins provided by the work of a smart contract (NuBits).

ECB stable-coins pegged to fiat currencies are described as digital units of value, while they are not a form of any particular currency; however, they rely on a certain set of stabilization instruments to minimize price fluctuations. According to the report, "tokenized coins" in the ECB classification are the most common type of stable-coins: they account for almost $97 \%$ of the total trading volume. The specified asset class also includes CBDC.

The emergence of stable-coins in general, and CBDC in particular, is due to the desire of participants in the financial market to use the opportunities and advantages offered by the blockchain to provide financial services; this was clearly demonstrated by cryptocurrencies, while reducing to zero the main disadvantages of cryptocurrencies, such as their high volatility and anonymity, which deprive their use as an equivalent alternative to a fiat currency (Sidorenko, 2019).

On the contrary, the predictable rate of the stable-coins allows us to make calculations even by long-term contracts between counterparties, to avoid a sharp devaluation of the coin (including through the manipulation of insider information in the financial markets), and use them as an equivalent replacement for the fiat currency. 
Most CBDCs are designed for general use, although some are used solely for bulk payments and settlements between central banks. In relation to CBDC, three models of access for their implementation are distinguished:

- Access only for financial institutions (Model FI)

- Access for the whole economy (Model EW)

- Access for financial institutions, plus limited access to banks supported by CBDC (Model FI+).

It is worth noting that digital currency of a central bank cannot match all the canons of cryptocurrencies, such as decentralization, change by voting, branching or the emergence of a new currency (fork), free purchase/ sale. The CBDC concept and the underlying distributed ledger technology (DLT) technology are today in the plane of a controversial discussion of their impact on the existing financial system. On the one hand, the objective advantages of DLT-based CBDCs are indisputable, which will allow central banks to reduce the use of cash, ensure 24/7 system availability, reduce transaction costs and terms, minimize costs and improve trade. Stablecoins also has undoubted benefits for exchanges, as they increase its level of decentralization and make the market drop not so significant for investors, and finally, if a stable-coin is well implemented, it can easily replace the US dollar in settlements.

Undoubtedly, the mega regulator of all countries see these advantages; it is confirmed by a close study of the issue of launching CBDC on their part.

BIS and FSB express serious concerns about the risks of launching a CBDC, in particular, about how fundamental the impact of the introduction of CBDC on the existing financial ecosystem will turn out, which ultimately casts doubt on the role of banks in financing economic activities and makes their universal release unlikely in the short term. In February 2019 FSB chairman Randal Quarles stated that stable-coins could challenge any financial structure, so G2O member countries should actively implement FATF standards for stable-coins.

Among the key risks for the global financial system, the $\mathrm{G} 7$ report notes the following:

1) The expansion of the circle of customers (the transition from a model of interaction with commercial banks to a multi-user audience) entails a significant increase in operational risks for central banks;

2) Difficulties in complying with the principles of Anti-Money Laundering (AML)/ Know Your Customer (KYC);

3) Replacing the functionality of commercial banks (payment processing) with blockchain, and as a result, a complete drop-in bank income; 
Alexandra Yuryevna Bokovnya, Zarina Ilduzovna Khisamova, Vitalii Fedorovich Vasyukov y Ildar Rustamovich Begishev

4) Difficulties in the p2p (peer-to-peer) lending system and in determining interest rates;

5) Containment of competition and a threat to financial stability if users suddenly lose confidence in digital currency.

In a separate letter to the G20 finance ministers, FSB Chairman Randal Quarles also noted that all these challenges "must be addressed as a matter of priority".

On April 14, 2020, the FSB provided general recommendations on regulating stable-coins. Thus, stable-coins must meet the same requirements that are followed by other organizations that carry similar risks, regardless of the technology used. That is, the DUE DILIGENCE and KYC/AML procedures should be strictly applied to stable-coins, which will allow at least partially to eliminating the risks. At the same time, it is noted that control over stable-coins used for making international payments is complicated by differences in financial regulation of different countries.

States are encouraged to be flexible and develop a common standard for regulating digital currencies so that their issuers cannot move from one jurisdiction to another. If necessary, the authorized bodies should specify regulation and eliminate possible gaps in the domestic legal system in order to effectively minimize the risks posed by international stable-coins. Special attention in the recommendations is given to stable-coin operators. Operators of stable cryptocurrencies must take measures for the effective management of risks and the stable operation of their system. In particular, they are required to provide protection against cyberattacks, to combat money laundering and the financing of terrorism. Also, according to the FSB, the possibility of free transactions using stable-coins is a serious threat to financial stability.

Meanwhile, it is worth dwelling on the distinctive advantage of CBDC, which takes on the nature of a problem in the global socio-political context. The spread of CBDC is able to streamline cross-border payments and create seamless trade without borders, which in turn means increased competition for global trade and, consequently, increased sovereignty over the global economy.

\section{Discussion}

As countries around the world continue to research and test the digital currencies of their central banks, it becomes increasingly apparent that the dominance of the US dollar can be called into question after the concept would be fully implemented on a regional scale. The US dollar remains an 
undisputed "king" when it comes to international trade. According to the International Monetary Fund, as of 2019, about 61\% of all foreign exchange reserves are allocated in dollars. Similarly, the sovereign currency of the United States serves as the primary vehicle for cross-border transactions, even for transactions in which the United States itself is not involved.

While most CBDC retailers focus on domestic economic issues, some projects focus on promoting trade in a specific region, creating a digital alternative to the US dollar.

Examples of such stablecoins are a regional stablecoin supported by a basket of currencies, including Chinese Yuan, Japanese Yen, South Korean Won and Hong Kong Dollar, which will allow East Asian countries to get rid of the hegemony of the US dollar. However, the support of CBDC with the national currencies of various states creates significant difficulties in providing the system, conducting KYC/AML procedures, as well as determining the centralized CBDC issuer and operator. Another example of a regional $\mathrm{CBDC}$ is the digital CBDC euro. The concept is most actively explored by the French Central Bank, Banque de France.

One of the main participants in the unofficial CBDC race is the digital yuan, a digital currency that is being actively developed by the People's Bank of China. According to the representative of the Chinese Central Bank, the "digital yuan" can be used on such large payment platforms as WeChat and Alipay. The security of China's cryptocurrency will be similar to that offered by paper money. In this case, the asset can be used without an Internet connection.

Challenging the dollar as a world trade currency is possible only if the base currency of the indicated CBDC is already the main world trade currency. The digital yuan is one of the few CBDC projects that have a real opportunity to squeeze the dollar because of China's trade relations and the great number of China's partners, which are scattered around the world, and the scale of world trade taking place with China.

It is noteworthy that the United States is also considering the possibility of placing its national currency on blockchain rails, which, if implemented correctly and quickly, can completely stop many competing projects.

Another alternative was the idea of creating a supranational CBDC for BRICS. At the beginning of 2018, the Russian Central Bank and Russian President V. Putin proposed to create an international digital currency common to the BRICS and the EAEU. Among the key advantages of such an initiative, there is the possibility of replacing the SWIFT system with blockchain technology, which will underlie such digital currency, as well as its lower susceptibility to possible devaluation in contrast to the national currencies already used in mutual trade settlements. 
Alexandra Yuryevna Bokovnya, Zarina Ilduzovna Khisamova, Vitalii Fedorovich Vasyukov y Ildar Rustamovich Begishev

The potential implementation of such a project could make it possible to ensure significant efficiency of trade relations within the group by reducing transaction costs, increasing their reliability, and in the future by completely changing the structure of trade relations through the introduction of blockchain technology and smart contracts. Such an idea looks particularly attractive against the background of news about the launch in the test mode of CBDC by the World Bank and the IMF to study the possibilities of digital assets and blockchain.

However, there are serious doubts about the real possibility of implementing such an initiative, first of all, in view of the diametrical opposite of the national approaches represented by developing countries to the regulation of digital currencies. It should be noted that the delay in creating a "single digital environment of trust" based on interstate agreements demonstrated against the background of the constant distancing of the national approaches shown by the countries of the group in the issue of regulating digital financial assets virtually eliminates the possibility of implementing such an initiative. The absence of a single agreed position on the legal nature of CBDC and its implementation strategy at the international level is reflected in the quality of national legal regulation of virtual currency (Shuvalov et al., 2017; Burnie, 2018; Carstens, 2019; Ciaian and Rajcaniova, 2018).

In brief it should be mentioned that the payment requirements and customer identity verification will allow at least partially eliminating the risks (Constâncio, 2018; Khisamova et al., 2019; Begishev and Khisamova, 2018; Khisamova and Begishev, 2019; Begishev et al., 2020; Khisamova et al., 2020; Corbet et al., 2018; Haig, 2017).

\section{Conclusion}

Digital innovations in the financial sector contribute to faster, cheaper, and more inclusive payments. The benefits that the CBDC have can significantly transform the global economic environment, reduce existing costs and stimulate the growth of the global economy thanks to access to markets for a wide range of entities. IMF insists on using CBDC to expand access to financial services, especially in poor countries where financial institutions are underdeveloped and not always accessible. However, such advantages can be realized only if there is a properly developed and regulated procedure for implementing CBDC. The rules applicable in the traditional financial industry must be applied to them. We are talking about payment requirements and customer identity verification. This will allow at least partially eliminating the risks. 
The global scaling of CBDC creates important problems and risks related to financial stability, monetary policy, guarantees to prevent money laundering and terrorist financing, as well as protecting consumers and investors from risks. However, control over stablecoins used to carry out international payments is complicated by differences in financial regulation of different countries. Digitalization of the economy is inextricably linked with the globalization of financial and economic regulation, and the need to solve a number of emerging problems, which is possible only in conditions of interaction at the interstate level.

\section{Acknowledgement}

The work is performed according to the Russian Government Program of Competitive Growth of Kazan Federal University.

\section{Bibliographic References}

BEGISHEV, Ildar; KHISAMOVA, Zarina. 2018. "Criminological Risks of Using Artificial Intelligence” In: Vserossiiskii kriminologicheskii zhurnal. Russian Journal of Criminology. Vol. 12 No. 6, pp. 767-775.

BEGISHEV, Ildar; KHISAMOVA, Zarina; NIKITIN, Serge. 2020. "The Organization of Hacking Community: Criminological and Criminal Law Aspects" In: Vserossiiskii kriminologicheskii zhurnal. Russian Journal of Criminology. Vol. 14 No. 1, pp. 96-105.

FUSARO, Trevor; HOUGAN, Matt. 2019. Bitwise Asset Management: Presentation to the U.S. Securities and Exchange Commission.

BURNIE, Andrew. 2018. Exploring the interconnectedness of cryptocurrencies using correlation networks. Conference Paper presented at The Cryptocurrency Research Conference Anglia Ruskin University Lord Ashcroft International Business School Centre for Financial Research. Cambridge, UK.

CARSTENS, Agustín. 2019. Money in the digital age: what role for central banks? Lecture at the House of Finance. Goethe University. Frankfurt, Germany.

CIAIAN, Pavel; RAJCANIOVA, Miroslava. 2018. "Virtual relationships: Shortand long-run evidence from BitCoin and altcoin markets. Journal of International Financial Markets" In: Institutions and Money. Vol. 52, pp.173-195. 
Alexandra Yuryevna Bokovnya, Zarina Ilduzovna Khisamova, Vitalii Fedorovich Vasyukov y Ildar Rustamovich Begishev

166 Assessment of Potential Risks of Regional for Global Financial Security

CONSTÂNCIO, Vitor. 2018. The future of monetary policy frameworks. Lecture at the Instituto Superior de Economia e Gestão. Lisbon, Portugal.

CORBET, Shaen; MEEGAN, Andrew; LARKIN, Charles; LUCEY, Brian; YAROVAYA, Larisa. 2018. "Exploring the dynamic relationships between cryptocurrencies and other financial assets" In: Economics Letters. Vol. 165, pp. 28-34.

HAIG, Sarah. 2017. Paradise Papers Reveal Bitfinex's Devasini and Potter Established Tether Already Back in 2014.

NABILOU, Hossein. 2019. Central bank digital currencies: preliminary legal observations. J. Bank. Regul. Available online. In: https://ssrn.com/ abstract $=3329993$. Consultation date: $19 / 06 / 2020$.

KHABRIEVA, Talia. 2016. "Legal Issues of Financial Security in Russia" In: Vestnik ekonomicheskogo pravosudiya Rossiiskoy Federatsii. Vol. 10, pp. 45-54 (in Russian).

KHISAMOVA, Zarina; BEGISHEV, Ildar. 2019. "Criminal Liability and Artificial Intelligence: Theoretical and Applied Aspects" In: Vserossiiskii kriminologicheskii zhurnal. Russian Journal of Criminology. Vol. 13 No. 4, pp. 564-574.

KHISAMOVA, Zarina; BEGISHEV, Ildar; LATYPOVA, Elina. 2020. "Digital Crime in the Context of a Pandemic: Main Trends" In: Vserossiiskii kriminologicheskii zhurnal. Russian Journal of Criminology. Vol. 14 No. 4, pp. 80-90.

KHISAMOVA, Zarina; BEGISHEV, Ildar; SIDORENKO, Elina. 2019. "Artificial Intelligence and Problems of Ensuring Cyber Security" In: International Journal of Cyber Criminology. Vol. 13 No. 2, pp. 564-577.

KUDRYASHOVA, Ekaterina. 2019. "Financial security in the hierarchy of strategic planning goals in the Russian Federation" In: Law. Journal of the Higher School of Economics. Vol. 2, pp. 124-138.

SHUVALOV, Igor; KHABRIEVA, Talia; JINGZHU, Fendar. 2017. Cyberspace of BRICS: Legal Dimension: Monograph. Moscow: Institute of Legislation and Comparative Law under the Government of the Russian Federation. Moscow, Russia.

SIDORENKO, Elina. 2019. Stablecoin as a new financial instrument. In: International Scientific Conference "Digital Transformation of the Economy: Challenges, Trends, New Opportunities" Springer. Cham, Switzerland.

VOROBYOV, Yukdena; PORITSKY, Davi. 2015. "Financial and economic security: theoretical aspect" In: Scientific Bulletin: finance, banks, investments. Vol. 2 No. 31, pp. 34-43. 


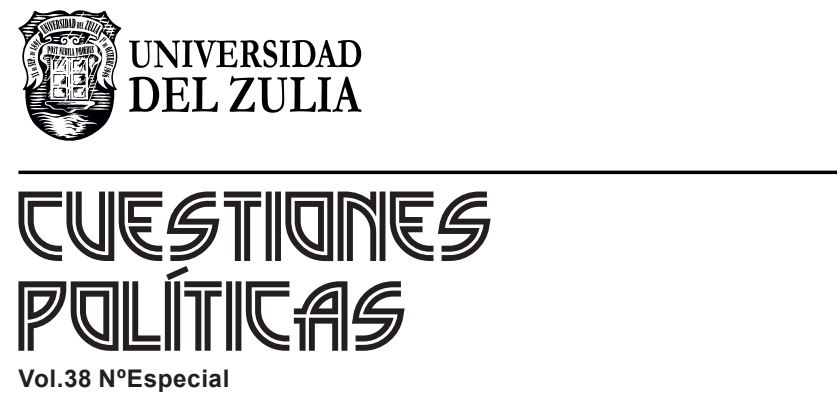

www.luz.edu.ve 